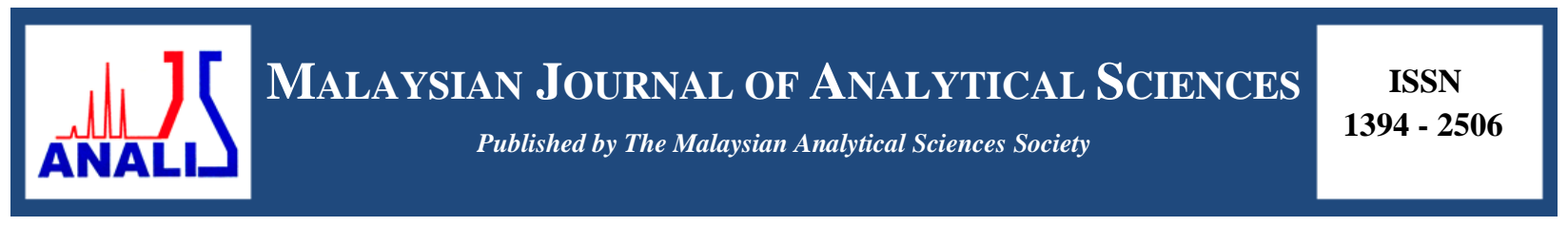

\title{
CHEMICAL COMPONENTS OF POLYMERASE CHAIN REACTION IN 18S rRNA FOR DETECTION OF Cryptosporidium FROM RIVER WATER SAMPLES
}

\author{
(Komponen Kimia Tindak Balas Berantai Polimerase di dalam 18S rRNA untuk Pengesanan \\ Cryptosporidium dari Sampel Air Sungai)
}

\author{
Mohd Aiman Barudin ${ }^{1}$, Mohammad Lokman Md Isa ${ }^{2,3}$, Afzan Mat Yusof ${ }^{2,3 *}$ \\ ${ }^{1}$ Department of Biomedical Science, Kulliyyah of Allied Health Sciences \\ ${ }^{2}$ Department of Basic Medical Sciences, Kulliyyah of Nursing \\ ${ }^{3}$ Integrated Cellular and Molecular Biology Cluster (iMolec) \\ International Islamic University Malaysia, Jalan Sultan Ahmad Shah, Bandar Indera Mahkota, \\ 25200 Kuantan, Pahang, Malaysia. \\ *Corresponding author: afzan@iium.edu.my
}

Received: 19 August 2018; Accepted: 18 May 2019

\begin{abstract}
The gene of $18 \mathrm{~S}$ ribosomal RNA or $18 \mathrm{~S}$ rRNA is the universal gene function as a general genetic marker for species identification of microorganisms including parasites. Cryptosporidium has distinct 18S rRNA genes along different species within the same genus. In this study, polymerase chain reaction or PCR was used to study chemical components of PCR setup in amplification of 18S rRNA gene of this parasite. Cryptosporidium was collected from river water samples and its presence was confirmed using specific immunofluorescence detection of this parasite. Isolated water containing Cryptosporidium was then subjected to genomic DNA extraction before PCR step. The chemical components of PCR consisting of $\mathrm{MgCI}_{2}$, deoxynucleotide triphosphate (DNTPs), Polymerases, free DNase-water, universal primers and PCR buffer were studied in different volume and concentration. Each chemical component of PCR was optimized differently in yielding the same final volume of $20 \mu \mathrm{L}$ per each reaction. The value range of chemical components of PCR consisted of $\mathrm{MgCI}_{2}(0.1 \mu \mathrm{M}-0.5 \mu \mathrm{M})$, dNTPs $(50-250 \mathrm{mM})$, free DNase water $(5-10 \mu \mathrm{L})$, polymerases $(0.2-0.5 \mathrm{U})$ and universal primers $(2-20 \mu \mathrm{M})$. The result indicated that $0.2 \mu \mathrm{M}$ of $\mathrm{MgCI}_{2}$, $100 \mathrm{mM}$ of dNTPs, less than $10 \mu \mathrm{L}$ of free DNase water, $0.5 \mathrm{U}$ of polymerases and $10 \mathrm{mM}$ of universal primers were the best combination to get better result for molecular identification of 18S rRNA Cryptosporidium. As a conclusion, accurate and proper concentration or volume of each PCR chemical components is essential for molecular identification of 18S rRNA Cryptosporidium gene. In future studies, study on gradient temperature parameters of PCR run can be included to study the chemical nature of amplified genes either in denaturation, annealing or extension steps.
\end{abstract}

Keywords: chemical, Cryptosporidium, polymerase chain reaction, 18S ribosomal RNA gene

\begin{abstract}
Abstrak
Gen 18S ribosomal RNA adalah gen universal yang berfungsi sebagai penanda genetik umum untuk pengenalpastian spesies mikroorganisma termasuk parasit. Cryptosporidium mempunyai gen 18S rRNA yang berlainan daripada spesies berbeza dalam genus yang sama. Dalam kajian ini, tindak balas berantai polymerase atau PCR digunakan untuk mengkaji komponen kimia susun atur PCR dalam amplifikasi gen 18S rRNA bagi parasit ini. Cryptosporidium telah diambil dari sampel air sungai dan disahkan kehadirannya menggunakan pengesanan immunopendaflour terhadap parasit ini. Sampel air yang diambil mengandungi Cryptosporidium yang kemudiannya diteruskan untuk pengekstrakan genomik DNA sebelum peringkat PCR. Komponen kimia PCR yang terdiri daripada $\mathrm{MgCI}_{2}$, deoksinukleotida trifosfat (dNTPs), polimerase, air yang bebas DNase, primer umum dan larutan penimbal PCR telah dikaji dalam isipadu dan kepekatan yang berbeza. Setiap komponen kimia PCR dioptimakan secara
\end{abstract}




\section{Mohd Aiman et al: CHEMICAL COMPONENTS OF POLYMERASE CHAIN REACTION IN 18S rRNA FOR DETECTION OF Cryptosporidium FROM RIVER WATER SAMPLES}

berbeza dalam menghasilkan isipadu akhir $20 \mathrm{uL}$ bagi setiap tindak balas. Nilai julat komponen kimia PCR terdiri daripada $\mathrm{MgCI}_{2}(0.1 \mu \mathrm{M}-0.5 \mu \mathrm{M})$, dNTPs $(50-250 \mathrm{mM})$, air bebas DNase $(5-10 \mu \mathrm{L})$, polimerase $(0.2-0.5 \mathrm{U})$ dan primer primer umum $(2-$ $20 \mu \mathrm{M})$. Keputusan menunjukkan bahawa $0.2 \mu \mathrm{M} \mathrm{MgCI}_{2}, 100 \mathrm{mM}$ dNTPs, air bebas DNase yang kurang daripada $10 \mu \mathrm{L}, 0.5 \mathrm{U}$ polimerase dan $10 \mathrm{mM}$ primer umum adalah kombinasi terbaik untuk mendapatkan dapatan yang lebih baik bagi pengenalpastian molekul Cryptosporidium 18S rRNA. Kesimpulannya, kepekatan atau isipadu yang tepat dan sesuai bagi setiap komponen kimia PCR adalah penting untuk pengenalpastian molekul gen Cryptosporidium 18S rRNA. Bagi kajian masa depan, kajian ke atas kecerunan parameter suhu untuk menjalani PCR boleh dimasukkan untuk mengkaji sifat semulajadi kimia pada gen yang diamplifikasi untuk peringkat-peringkat penyahaslian, pelekatan atau penyambungan.

Kata kunci: kimia, Cryptosporidium, tindak balas rantai polimerase, gen 18S ribosomal RNA

\section{Introduction}

Cryptosporidiosis is prevalent in developing countries, perhaps because the high contamination from environmental and hygiene conditions [1]. In contrast, the cryptosporidiosis transmission in developed countries is possibly not similar as compared to developing countries. Cryptosporidium oocysts are frequently found in contaminating surface waters because of anthroponotic activity, agricultural practices, sewage effluent, native animal or livestock fecal contamination as well as extremely resistant to chlorine and monochloramine for water disinfection [2]. In addition to being resistant to commonly used disinfectant chemicals, it is commonly considered that oocysts can persist for several months or more in the aquatic environment [3]. Other than that, the relatively low infectious dose of Cryptosporidium at least 10 oocysts can pose a challenge to water utilities for provision of purified drinking water [4]. To date, this parasitic occurrence has been reported in different geographical location of river [5]. In fact, $11.5 \%$ of Malaysian river water samples were reported to get contaminated with Cryptosporidium oocysts [6]. Recently, two cases have been reported on Cryptosporidium occurrence in Kuantan, Pahang [7,8].

Meanwhile, amplification of $18 \mathrm{~S}$ rRNA gene loci is been the most widely accepted method to provide information on species identification [9]. An optimized method of PCR for Cryptosporidium oocysts is essential in detection of single loci with specific primers. DNA extraction for this parasite turns to be effective once disruption of the robust oocyst wall takes place for releasing sporozoite nuclei. Meanwhile detachment of DNA and histone protein is important for primer to have accessibility to anneal and thus, facilitating the amplification of specific DNA sequence using PCR [10]. It is a challenge for diagnosing Cryptosporidium to the species/genotype level due to the lower occurrence and the rich presence of PCR inhibitors from environmental water samples. It is essential for the public and environmental health assessment for identifying the contamination sources of Cryptosporidium oocysts [11]. In addition, optimization of chemical constituents of PCR reagents is also important to get correct amplicon of PCR upon the completion of PCR with the specific primer on annealing specific gene sequences [12]. All chemical reagents like dNTPs, $\mathrm{MgCI}_{2}$, primers, polymerases and water have their own limitation either low or high proportion could lead to successfulness of PCR [13]. Manipulation of chemical nature of those chemical reagents can be useful to set up a better reaction mix of PCR prior to run the reaction [14]. Thus, in this study, chemical reagent constituents of PCR are optimized accordingly to result in successfulness of PCR on amplification of Cryptosporidium 18S rRNA gene.

\section{Collection of river water samples}

\section{Materials and Methods}

This study was carried out in Kuantan and Balok, Pahang. The upstream, midstream and downstream area in both Kuantan River and Balok River were selected as the sampling sites. Kuantan River runs from Lembing River through Kuantan City where this city is located near the mouth of Kuantan River before this river flows out to the South China Sea. Meanwhile, Balok River is located close to industrial area and residential area in Gebeng area and Balok city, respectively.

\section{Water processing}

United States Environmental Protection Agency 1623.1 method was used to detect Cryptosporidium from river water samples [15]. River water samples were processed to be concentrated using continuous flow centrifuge (CFC Express System) (Scientific Methods Inc, Granger, Indiana, USA) prior to immunomagnetic separation using Dynabeads® GC-Combo (Dynal, Cat. no. 730.02, Oslo, Norway). 


\section{Fluorescein isothiocyanate staining}

Purified oocysts of river water samples were stained using a fluorescein isothiocyanate labelled monoclonal antibody kit specific to Cryptosporidium oocysts (Cellabs Pty Ltd., cat. no. KR2111A6, Brookvale, Australia) and then were examined using fluorescence microscope under 400x magnification.

\section{DNA extraction from water samples}

DNA of Cryptosporidium oocysts from river water sample was extracted by using QIAamp DNA Mini Kit (QIAGEN, Germany) with minor modifications.

\section{Optimization of chemical components in PCR reaction mixture}

Each chemical component of PCR was optimized differently in yielding the same final volume of $20 \mu \mathrm{L}$ per each reaction. The value range of chemical components of PCR consists of $\mathrm{MgCI}_{2}(0.1 \mu \mathrm{M}-0.5 \mu \mathrm{M})$, dNTPs $(50-250$ $\mathrm{mM})$, free DNase water (5-10 $\mu \mathrm{L})$, polymerases (0.2-0.5 $\mathrm{U})$ and universal primers $(2-20 \mu \mathrm{M})$. The results of several PCR reactions in different volume of PCR chemical components were run based on nested PCR.

\section{Identification of $18 S$ rRNA sequence}

Nested PCR of 18S rRNA was carried out for Cryptosporidium genotyping [16]. Purified commercially genomic DNA of C. parvum was set to be a positive control. Distilled water was used as a negative control for nested PCR. Agarose solution (1.2\%) was prepared with $1 \mu \mathrm{L}$ GelRed. The gel was electrophoresed at $100 \mathrm{~V}$ for 40 min and then visualized using GelDoc Ez System (Bio-Rad).

\section{Results and Discussion}

Out of six river water samples, five were detected with Cryptosporidium. The findings were confirmed by using $18 \mathrm{~S}$ rRNA-based PCR method. The result of secondary PCR products of 18S rRNA gene showed that only one sample from upstream point of Kuantan River did not appear a single band on the $1.2 \%$ agarose gel. In this study, the positive results of genotyping approach showed that only five water samples out of six samples from two rivers contained DNA of Cryptosporidium oocysts. A previous study had revealed distribution of Cryptosporidium species in river water samples of Kuantan River and Balok River, especially at downstream point [7, 8]. Each chemical component of PCR was optimized differently in yielding the same final volume of $20 \mu \mathrm{L}$ per each reaction. The value range of chemical components of PCR consisted of $\mathrm{MgCI}_{2}(0.1-0.5 \mu \mathrm{M})$, dNTPs (50-250 mM), free DNase water $(5-10 \mu \mathrm{L})$, polymerases $(0.2-0.5 \mathrm{U})$ and universal primers $(0.1-0.5 \mu \mathrm{M})$. The result indicated that $2 \mathrm{mM}$ of $\mathrm{MgCI}_{2}, 100 \mathrm{mM}$ of DNTPs, less than $10 \mu \mathrm{L}$ of free DNase water, $0.5 \mathrm{U}$ of polymerases and $10 \mathrm{mM}$ of universal primers were the best combination to get acceptable results for molecular identification of 18S rRNA Cryptosporidium. To understand the function of chemical reagents used in this study, it is critical to optimize and troubleshoot the optimal PCR conditions at a time in obtaining the desired PCR product of Cryptosporidium 18S rRNA gene (Table 1). However, unbalanced composition of PCR chemical reagents may cause non-specific amplicons and reduce PCR specificity [17].

Table 1. Different volumes of PCR chemical components in nested PCR

\begin{tabular}{lcccc}
\hline $\begin{array}{l}\mathbf{M g C I}_{2} \\
(\boldsymbol{\mu M})\end{array}$ & $\begin{array}{c}\text { dNTPs } \\
(\mathbf{m M})\end{array}$ & $\begin{array}{c}\text { Free-DNaseWater } \\
(\boldsymbol{\mu} \mathbf{L})\end{array}$ & $\begin{array}{c}\text { DNA } \\
\text { Polymerases } \\
(\mathbf{U})\end{array}$ & $\begin{array}{c}\text { Universal Primers } \\
(\boldsymbol{\mu M})\end{array}$ \\
\hline 0.1 & 50 & 5 & 0.2 & 2 \\
0.2 & 100 & 6 & 0.3 & 8 \\
0.3 & 150 & 7 & 0.4 & 12 \\
0.4 & 200 & 8 & 0.45 & 16 \\
0.5 & 250 & 9 & 0.5 & 20 \\
\hline
\end{tabular}


In this study, Taq DNA polymerase was used as it is suitable for obtaining desired amplicon products and more efficient as a hot start PCR [18]. Normally, the molar concentration of polymerase is comparatively low as compared to other chemical reaction components as recommended volume supplied is $1-2.5$ Units per $100 \mu \mathrm{L}$ reaction volume. Reduced concentration of polymerases ensure specificity while higher counterpart causing nonspecific amplicons [19]. DNA polymerases are favored in PCR process with a cofactor like magnesium ion [20]. They are easily manipulated resulting in the stringency of PCR as its ionic concentration is critical. In fact, it is also determined by EDTA in PCR buffer and deoxynucleotide 5'-triphosphates (dNTPs). In principle of PCR chemistry, dNTP- $\mathrm{Mg}^{2+}$ soluble complexes tend to interact with the DNA template backbone thereby activating DNA polymerase function (Figure 1). Soluble complexes are recognized as a substrate for DNA polymerase to act on [21]. However, increased magnesium ion can reduce polymerase specificity, stabilize the duplex strand of DNA template or fidelity of Taq DNA polymerase, stabilize the duplex strand of DNA template and spurious incorrect primer annealing thereby resulting in undesired or non-specific amplicons [22]. In contrast, insufficient concentration of $\mathrm{Mg}^{2+}$ can cause no amplicons or yields are likely to be poor [23]. $\mathrm{MgCI}_{2}$ was optimized in this study because the reaction cannot proceed without the sufficient concentration of $\mathrm{Mg}^{2+}$ ion. The optimized concentration is additional option from the recommended protocol because the nature of DNA template can be affected by PCR inhibitors from environmental factors [24]. In such case, it is crucial to increase the concentration of magnesium ion for PCR stringency and specificity.

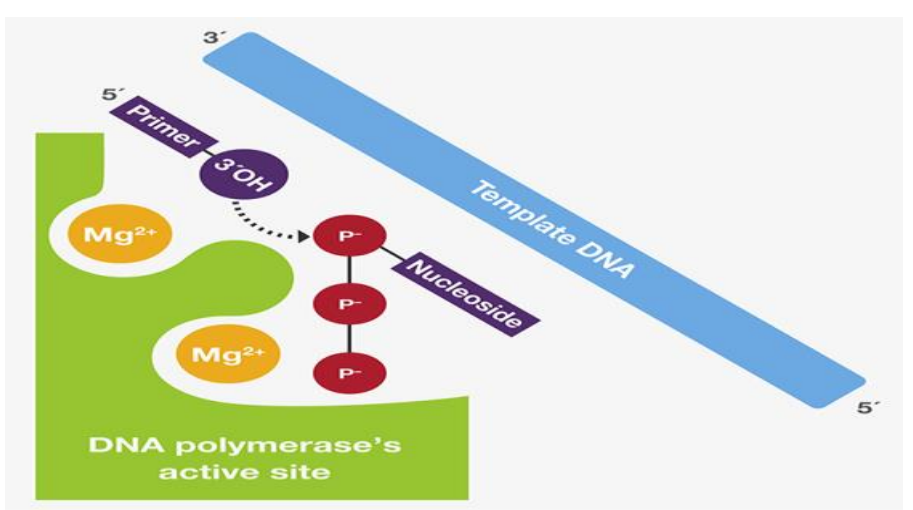

Figure 1. Illustration of polymerase chain reaction on DNA molecules along with other PCR chemical components involved in the PCR reaction

On the other hand, four dNTPs should be at the appropriate equivalent concentrations of $50 \mu \mathrm{M}$ even though the reaction commonly can compromise between 20 and $200 \mu \mathrm{M}$ [25]. In our study, dNTPs were optimized accordingly from the lowest to highest concentration to find an optimal concentration that is suitable for PCR reaction. Reduced dNTPs concentrations can increase PCR specificity while higher one can work oppositely [26]. The desired length of PCR products is not long, below $500 \mathrm{bp}$ and thus, higher dNTP concentration is not required. In our practice, optimization of each dNTP is essential for working dNTPs solution to reach the optimal balance in final reaction coupled with other PCR reagents. It is important that four dNTP's concentrations should be used equivalently for minimizing misincorporation errors [27]. One of the main components to be discussed is universal primers. Its concentration should be optimal at 0.1-0.5 $\mu \mathrm{M}$. In our study, primer was optimized for both concentrations and final volume in $20 \mu \mathrm{L}$ PCR reaction mix. Higher concentration of universal primers can result in template mis priming at non-specific sites and thus, leading to accumulated non-specific products formation [28]. However, the primers should be prepared at slightly higher concentration than optimal to avoid of its exhaustion that possibly compromise the desired amplicon yield upon PCR completion [29]. Finally, free-DNase water is generally the easiest component for optimization since it is essentially important to be included in PCR reaction mix for avoiding any residual enzymatic activity such as DNase that can degrade DNA template during PCR reaction until its completion [30]. However, the volume of water should not higher than half of PCR mix volume. In our study, the volume of PCR mix was set to be at $20 \mu \mathrm{l}$ per reaction only. Thus, it is only tolerated for manipulation below than $10 \mu \mathrm{L}$ to avoid diluting other essential chemical components of PCR such as DNA polymerase, dNTPs, MgCI2 and universal 
primers as primers were already diluted from its working concentration of primer stock. Equal concentration of dNTPs with the excessive volume of water in PCR reaction mix indirectly can affect the formation of desired amplicon upon PCR completion [31].

\section{Conclusion}

Accurate and proper concentration or volume to each PCR chemical components is essential for molecular identification of $18 \mathrm{~S}$ rRNA Cryptosporidium gene. These optimized PCR chemical components can be applied to other water samples infected with Cryptosporidium for species identification. In future studies, study on gradient of temperature parameters of PCR run can be included to study the chemical nature of amplified genes either in denaturation, annealing or extension steps.

\section{Acknowledgement}

The authors acknowledge to International Islamic University Malaysia (IIUM) for financial support through PRIGS18-037-0037.

\section{References}

1. Shrivastava, A. K., Kumar, S., Smith, W. A. and Sahu, P. S. (2017). Revisiting the global problem of cryptosporidiosis and recommendations. Tropical Parasitology, 7(1): 8.

2. Huang, C., Hu, Y., Wang, L., Wang, Y., Li, N., Guo, Y., Feng, Y. and Xiao, L. (2017). Environmental transport of emerging human-pathogenic Cryptosporidium species and subtypes through combined sewer overflow and wastewater. Applied and Environmental Microbiology, 83(16): AEM-00682.

3. Sales-Ortells, H., Agostini, G. and Medema, G. (2015). Quantification of waterborne pathogens and associated health risks in urban water. Environmental Science \& Technology, 49(11): 6943-6952.

4. Adamska, M., Sawczuk, M., Kolodziejczyk, L. and Skotarczak, B. (2015). Assessment of molecular methods as a tool for detecting pathogenic protozoa isolated from water bodies. Journal of Water and Health, 13(4): 953959.

5. Zahedi, A., Paparini, A., Jian, F., Robertson, I. and Ryan, U. (2016). Public health significance of zoonotic Cryptosporidium species in wildlife: critical insights into better drinking water management. International Journal for Parasitology: Parasites and Wildlife, 5(1): 88-109.

6. Triviño-Valencia, J., Lora, F., Zuluaga, J. D. and Gomez-Marin, J. E. (2016). Detection by PCR of pathogenic protozoa in raw and drinkable water samples in Colombia. Parasitology Research, 115(5): 1789-1797.

7. Afzan, M. Y., Mardhiah, M., Muhammad Razman, A. R., Qamarul Iqmal, A., Sharmeen Nellisa, S., Nur Hazirah, H., Najat, H. and Ridhwan, A. W. (2015). The occurrence Cryptosporidium oocysts in selected rivers and its physical assessments in Kuantan, Pahang. Journal of Applied Science Research, 11(17): 19-25.

8. Mohd Aiman, B., Muhammad Lokman, M. I. and Afzan, M. Y. (2017). First molecular characterization of Cryptosporidium from three different points of two main rivers in Kuantan, Malaysia using 18S rRNA gene nested PCR. Asian Pacific Journal of Tropical Disease, 7(9): 930-934.

9. Thompson, R. C. A. and Ash, A. (2016). Molecular epidemiology of Giardia and Cryptosporidium infections. Infection, Genetics and Evolution, 40: 315-323.

10. Richard, R. L., Ithoi, I., Abd Majid, M. A., Wan Sulaiman, W. Y., Tan, T. C., Nissapatorn, V. and Lim, Y. A. L. (2016). Monitoring of waterborne parasites in two drinking water treatment plants: A study in Sarawak, Malaysia. International Journal of Environmental Research and Public Health, 13(7): 641.

11. Lim, Y. A., Mahdy, M. A. and Surin, J. (2013). Unravelling Cryptosporidium and Giardia in Southeast Asia. In Parasites and their vectors. Springer, Vienna: pp. 77-102.

12. Al-Delaimy, A. K., Al-Mekhlafi, H. M., Nasr, N. A., Sady, H., Atroosh, W. M., Nashiry, M., Anuar, T. S., Moktar, N., Lim, Y. A. and Mahmud, R. (2014). Epidemiology of intestinal polyparasitism among Orang Asli school children in rural Malaysia. PLoS Neglected Tropical Diseases, 8(8): e3074.

13. Kumar, T., Onichandran, S., Lim, Y. A., Sawangjaroen, N., Ithoi, I., Andiappan, H., Salibay, C. C., Dungca, J. Z., Chye, T. T., Sulaiman, W. Y. and Lau, Y. L. (2014). Comparative study on waterborne parasites between Malaysia and Thailand: A new insight. The American Journal of Tropical Medicine and Hygiene, 90(4): 682689.

14. Lim, Y. A. L. and Vythilingam, I. (Eds.). (2014). Parasites and their vectors: A special focus on Southeast Asia. Springer Science \& Business Media. 
15. United States Environmental Protection Agency (2012). Method 1623.1: Cryptosporidium and Giardia in water by filtration/IMS/FA. Cincinnati: United States Environmental Protection Agency. http://www.doc88.com/p0416866100459.html [Access online 3 July 2018].

16. Mahmoudi, M. R., Nazemalhosseini-Mojarad, E., Kazemi, B., Haghighi, A., Mirzaei, A., Mohammadiha, A., Jahantab, S., Xiao, L. and Karanis, P. (2015). Cryptosporidium genotypes and subtypes distribution in river water in Iran. Journal of Water and Health, 13(2): 600-606.

17. Lee, S. C., Ngui, R., Tan, T. K., Roslan, M. A., Ithoi, I. and Lim, Y. A. (2014). Aquatic biomonitoring of Giardia cysts and Cryptosporidium oocysts in peninsular Malaysia. Environmental Science and Pollution Research, 21(1): 445-453.

18. Hall, T. (2011). BioEdit: An important software for molecular biology. GERF Bulletin Bioscience, 2(1): 60-61.

19. Kumar, S., Stecher, G. and Tamura, K. (2016). MEGA7: Molecular evolutionary genetics analysis version 7.0 for bigger datasets. Molecular Biology and Evolution, 33(7): 1870-1874.

20. Zainal Abidin, Z. A., Abdul Malek, N., Zainuddin, Z. and Chowdhury, A. J. K. (2016). Selective isolation and antagonistic activity of actinomycetes from mangrove forest of Pahang, Malaysia. Frontiers in Life Science, 9(1): 24-31.

21. Ghani, N. A. A. A., Othman, N. and Baharudin, M. K. H. (2013). Study on characteristics of sediment and sedimentation rate at Sungai Lembing, Kuantan, Pahang. Procedia Engineering, 53: 81-92.

22. Ghani, N. A. A., Mohamad, N. A. and Hui, T. W. (2016). Rainfall analysis to determine the potential of rainwater harvesting site in Kuantan, Pahang. ARPN Journal of Engineering Applied Science, 11(11): 72647268.

23. Alshaebi, F. Y., Yaacob, W. Z. W., Samsudin, A. R. and Alsabahi, E. (2009). Risk assessment at abandoned tin mine in Sungai Lembing, Pahang, Malaysia. Electronic Journal of Geotechnical Engineering, 14: 1-9.

24. Le Blancq, S. M., Khramtsov, N. V., Zamani, F., Upton, S. J. and Wu, T. W. (1997). Ribosomal RNA gene organization in Cryptosporidium parvum. Molecular and Biochemical Parasitology, 90(2): 463-478.

25. Xiao, L., Escalante, L., Yang, C., Sulaiman, I., Escalante, A. A., Montali, R. J., Fayer, R. and Lal, A. A. (1999). Phylogenetic analysis of Cryptosporidium parasites based on the small-subunit rRNA gene locus. Applied and Environmental Microbiology, 65(4): 1578-1583.

26. Stenger, B. L., Clark, M. E., Kváč, M., Khan, E., Giddings, C. W., Dyer, N. W., Schultz, J. L. and McEvoy, J. M. (2015). Highly divergent $18 \mathrm{~S}$ rRNA gene paralogs in a Cryptosporidium genotype from eastern chipmunks (Tamias striatus). Infection, Genetics and Evolution, 32: 113-123.

27. Ikarashi, M., Fukuda, Y., Honma, H., Kasai, K., Kaneta, Y. and Nakai, Y. (2013). First description of heterogeneity in 18S rRNA genes in the haploid genome of Cryptosporidium andersoni Kawatabi type. Veterinary Parasitology, 196 (1-2): 220-224.

28. Jellison, K. L., Distel, D. L., Hemond, H. F. and Schauer, D. B. (2004). Phylogenetic analysis of the hypervariable region of the $18 \mathrm{~S}$ rRNA gene of Cryptosporidium oocysts in feces of Canada geese (Branta canadensis): evidence for five novel genotypes. Applied and Environmental Microbiology, 70 (1): 452-458.

29. Ruecker, N. J., Matsune, J. C., Wilkes, G., Lapen, D. R., Topp, E., Edge, T. A., Sensen, C. W., Xiao, L. and Neumann, N. F. (2012). Molecular and phylogenetic approaches for assessing sources of Cryptosporidium contamination in water. Water Research, 46(16): 5135-5150.

30. Yang, B., Wang, Y. and Qian, P. Y. (2016). Sensitivity and correlation of hypervariable regions in 16S rRNA genes in phylogenetic analysis. BMC Bioinformatics, 17(1): 135.

31. Xiao, L., Limor, J. R., Li, L., Morgan, U., Thompson, R. C. and Lal, A. A. (1999). Presence of heterogeneous copies of the small subunit rRNA gene in Cryptosporidium parvum human and marsupial genotypes and Cryptosporidium felis. The Journal of Eukaryotic Microbiology, 46(5): 44S. 